\title{
JUDICIAL CORPORAL PUNISHMENT
}

\author{
Ole Martin Moen
}

$\prod$

UNISHMENTS have an air of paradox to them. In a typical case, we punish a criminal because they have inflicted a serious harm onto another, for example by committing robbery, battery, rape, or arson. In contrast to the clearly helpful responses that are provided by hospitals, domestic violence shelters, and fire departments, however, the responses that we call punishments, and that are provided by justice departments, do not aim at alleviating harms that have previously been inflicted. Rather, they aim at inflicting further harms, this time onto the perpetrator of the crime.

That a punishment is intended to inflict harm, at least temporarily, onto the person who is punished is arguably a necessary condition for an action to qualify as a punishment in the first place. If we sentence a man to forced rehabilitation, this might well be unpleasant for him, but unless the unpleasantness is part of what we aim for, then we are not trying to punish him-and in that case we might just as well try to make the rehabilitation comfortable. Admittedly, we often seek simultaneously both to rehabilitate and to punish; we might, for example, want to help a convicted spousal abuser to become better at controlling his anger, but because he beat his wife so violently, we also want him to suffer a bit along the way to rehabilitation. In that case, what we do counts both as rehabilitation and as punishment.

Why punish? There are, famously, two classical justifications of punishment. According to the retributivist justification some people deserve to be punished: they have done something wrong and they ought to pay for it so that justice will be restored, or come closer to being restored. The wife beater in the above example, we might think, deserves to suffer because of the suffering that he inflicted on his wife. The other classical justification, the consequentialist justification, does not depend on desert, but on the punishment being expected to discourage the convict himself and/or others from committing similar crimes in the future and, perhaps, to discourage private revenge. Contrary to the retributivist justification, which is backwards looking, the consequentialist justification is forward-looking. (Notice that incapacitation and rehabilitation, although 
they might be aims of incarceration, are not here taken to be aims of punishment. More on this below.)

In this paper I will not take sides in the debate about the ethical justification of punishment. For all I argue here, retributivism might be right, consequentialism might be right, or some other theory—perhaps a hybrid theory-might be right. ${ }^{1}$ I shall assume, however, that some justification of punishment is sound, such that in at least some cases we are justified in punishing at least some people for at least some of their actions. ${ }^{2}$

If we accept that we are sometimes justified in punishing, we must answer a number of questions before we can put a punishment regimen into practice:

1. Which actions should be punishable?

2. How severe should the various punishments be?

3. Which method(s) of punishment should be used?

Most normative discussions about punishment are concerned with the first and the second question. The third question, the question of method, is seldom debated other than in relation to capital punishment. Outside of that debate, it is often assumed that the range of permissible methods is restricted to incarceration, fines, and service to society.

In this paper I ask if judicial corporal punishment might also be justifiable. More specifically, and for the sake of giving the discussion an unambiguous target, I shall consider the method of judicial caning that is used in Singapore. A crucial feature of this punishment method is that it is very painful, yet it involves only very small long-term health risks. The upper limit of strokes in Singapore is twenty-four; it is carried out on the buttocks; the convict wears protective gear to avoid damage to spine and kidneys; and a medical doctor oversees the process. The punishments take place inside prisons, never in public. ${ }^{3}$ When I speak of caning in what follows, I refer to caning as it is carried out in Singapore.

I shall argue that if incarceration is a justifiable method of punishment, then so is this type of judicial corporal punishment. Although this is an unpopular position, a small number of contemporary academics defend (or tentatively defend) certain forms of corporal punishment. Among criminologists, Graeme Newman defends electroshock by appeal to a retributive theory of punishment, and Peter Moskos makes the case that convicts should be given the option to

1 I shall remain agnostic on the question of whether my thesis is compatible with a communicative theory of punishment. See Duff, Punishment, Communication, and Community.

2 For a strong case against punishment, see Boonin, The Problem of Punishment.

3 World Corporal Punishment Research, "Judicial Caning in Singapore, Malaysia and Brunei." 
choose corporal punishment as an alternative to incarceration. ${ }^{4}$ Among philosophers, David Benatar defends the corporal punishment of children, and Geoffrey Scarre defends, on utilitarian grounds, corporal punishment both in schools and in the judicial system. ${ }^{5}$ My argument for the judicial use of corporal punishment in this paper lies closest to Scarre's, but I do not tie my argument to utilitarianism, and while Scarre discusses historical and conceptual issues in greater detail than I do here, I investigate how corporal punishment relates to other forms of state violence, to incapacitation and rehabilitation, and to what we know about cognitive biases.

The most elaborate critique of corporal punishment is Patrick Lenta's Corporal Punishment: A Philosophical Assessment. ${ }^{6}$ Lenta is primarily concerned with criticizing the corporal punishment of children, but he also advances a number of arguments against its judicial use.

Since I discuss many arguments in this paper, I will be able to address some of them only rather briefly. By systematizing the debate and providing a bird'seye perspective on (what I take to be) the strongest arguments both for and against judicial corporal punishment, I hope to show that in spite of its downsides — which are real and should be taken very seriously - the overall case in favor of using this punishment method is strong. I also hope to show, by way of example, that by giving corporal punishment serious consideration we will be in a position to think more clearly and honestly about what we are doing when we punish.

I start by discussing what I call the naive objections to corporal punishment. I then present six central advantages of corporal punishment (compared to incarceration) before I consider a number of better objections.

\section{THE NAIVE OBJECTIONS}

A straightforward objection to judicial corporal punishment, including judicial caning, is that it harms convicts, and that this gives us reason, perhaps sufficient reason, to reject it. The first premise of this argument, that caning harms convicts, is certainly true. Caning makes convicts much worse off at the time when it happens and, in many cases, also worse off in the future. The fact that a particular method of punishment harms the person who is punished, however, cannot by itself constitute an objection in a debate about which method of punishment we should use, because all punishments aim at inflicting some form of harm. To

4 Newman, Just and Painful; Moskos, In Defense of Flogging.

5 Benatar, "Corporal Punishment"; Scarre, "Corporal Punishment."

6 Lenta, Corporal Punishment. 
reject a punishment method simply by appeal to the fact that it harms the person who is punished is therefore not to reject one punishment method among others, but rather, to reject the very idea of punishment. The objection is therefore naive in the sense that it does not take adequately into account that if we accept that we should sometimes punish, we accept that we should sometimes intentionally cause harm, at least temporarily.

According to another variant of the objection, corporal punishment should be rejected, not simply on the grounds that it is harmful, but on the grounds that it is too harmful. On this view, the pain that convicts feel when caned is so excruciating that it is impermissible. This is a better objection. This objection is also naive, however, since it seems that many variants of corporal punishment are overall less harmful than many variants of widely accepted punishments, such as incarceration. In making this point, Moskos asks us to consider what one should choose if one had to choose either five years in prison or ten lashes with a whip. ${ }^{7}$ Although ten lashes would be very bad, so surely would five years in prison. If I were confronted by this choice, I would almost certainly choose the ten lashes. If you have the same priorities, then it seems that you also judge ten lashes to be a lesser harm overall than five years in prison. But if that is your view, and you simultaneously think that five years in prison is sometimes a justifiable punishment, then you cannot reject ten lashes simply by saying that it is too harmful. You would need other arguments in order to reject this type of punishment. (If ten lashes and five years does not convince you, subtract lashes and add years until you reach the point at which you would prefer the lashes. Then ask yourself if the corresponding number of years is a punishment that you think states may rightfully impose.)

A lesson that we can learn from considering these two objections is that the question of punishment method (question three above) is different from the question of punishment severity (question two above). Many corporal punishments, for example those involving just one or two lashes, are clearly less severe overall than long-term prison sentences. It is important to keep in mind, moreover, that when we consider whether judicial corporal punishment can be justified, we should not just consider the most extreme versions (such as extreme beatings that render the victim incapacitated for weeks, months, or life), just like when we consider incarceration, we should not just consider imprisonment for life under terrible conditions. If we argue only against the most severe variants of a punishment method, we leave open the question of whether less severe variants might nevertheless be justified.

Just as the question of method is distinct from the question of severity, the

7 Moskos, In Defense of Flogging, 9. 
question of method is also distinct from the question of which actions should be punishable (i.e., question one above). In some countries, criticizing the government can lead to corporal punishment. In 2014 Raif Badawi was sentenced to 1,000 lashes as a punishment for "insulting Islam" by blogging about human rights issues in Saudi Arabia. I, a cautious supporter of judicial corporal punishment, believe that I can criticize Saudi Arabia's treatment of Badawi as harshly as anyone. My criticism, however, would not simply be that what Saudi Arabia did is wrong because it inflicted a corporal punishment, since on my view, the fact that a punishment is a corporal punishment is insufficient to reject it. The problem, I would say, is that Badawi was given a very severe punishment for doing something that should not be a punishable offense at all. Had he been imprisoned for life for the same actions, it could have been equally (or perhaps even more) appalling.

In what follows I shall not consider merciless beatings for criticizing an authoritarian state. Hopefully, we all agree that that is wrong, so there is little reason to debate it. What I shall consider is caning as a punishment for crimes that should (presumably) be punishable offenses anyway, such as rape, assault, robbery, and corruption.

\section{SIX ADVANTAGES OF CORPORAL PUNISHMENT}

What considerations count in favor of judicial corporal punishment? One advantage of corporal punishment, which has been pointed out by Newman, is that it "punishes the offender, and only the offender, for the offense. Prison in contrast punishes innocent people, such as the offender's family, by depriving it of his or her support."

Since the collateral damage from incarceration is vast, this is a significant comparative advantage. Every year thousands of children have their families broken apart because a parent is incarcerated, and many of these children must relocate due to financial difficulties or be turned over to foster care. In many cases, incarceration also deprives other dependents, such as the convict's spouse or parents, of a caregiver. ${ }^{9}$ Here corporal punishment has an advantage. Although it is certainly distressing to know that a family member receives corporal punishment, the family need not be broken up for more than a few days, and since the convict will almost always be able to return to normal life again soon, the punishment is much less likely to bring financial ruin.

Some children of convicts ought to be turned over to foster care. It is difficult

8 Newman, Just and Painful, 8.

9 Parke and Clarke-Stewart, "From Prison to Home." 
to deny, however, that it is better if this decision can be made separately and is not a consequence of the very method of punishment.

A second and related advantage is that corporal punishment does not destroy the social and economic networks that convicts depend upon for successful reintegration into society after they have served their sentence. Many convicts lose their work, families, and relationships as a result of imprisonment, which in turn can make it difficult for them to reintegrate into society after release and comparatively more tempting to return to crime. Corporal punishments, which concentrate the punishment into a short time frame, make this much less of a problem.

Admittedly, some convicts have no work and no dependents, and some benefit from being isolated from a criminal environment. My thesis in this paper, however, is that corporal punishment is sometimes justified, not that incarceration is never justified. I certainly acknowledge that in some cases, incarceration is the better option.

A third advantage is that corporal punishment does not cause convicts to socialize over long stretches of time with other convicts. In prison this is virtually unavoidable, which is unfortunate insofar as we want to discourage convicts from returning to crime after they are released, and insofar as forming relationships with other convicts is criminogenic. ${ }^{10}$

A fourth advantage is that, arguably, corporal punishment is fairer than incarceration. Today, inmates that are physically intimidating will often be safer in prison than less intimidating inmates, who are more likely to be extorted, abused, and raped. Human Rights Watch estimates that, in sum, approximately 140,000 prison inmates are raped in the United States every year. ${ }^{11}$ Transgender inmates are particularly vulnerable to both sexual and nonsexual violence. ${ }^{12}$ We also know that inmates that are convicted of certain types of crimes, especially sexual offenses involving children, tend to be treated very badly in prison. ${ }^{13}$ Even if we think that child sex offenders deserve harsh punishment, we should codify that into our laws and not let the severity of their punishments depend on morally arbitrary factors such as who the convict's co-inmates are and how intimidating they are compared to the convict. It could be argued that the obvious response to this problem is to work to improve the safety of prison inmates. I agree that we ought to do that, but until or unless we succeed, corporal punishment is nevertheless advantageous in this respect.

For a detailed discussion of this point, see Scarre, "Corporal Punishment"; and Moskos, In Defense of Flogging.

Mariner, No Escape.

Edney, "To Keep Me Safe from Harm?"

Trammell and Chenault, "'We Have to Take These Guys Out.” 
A fifth advantage is that corporal punishment is likely to have a stronger deterrent effect than incarceration per unit of harm that is inflicted on the convict. One reason for this is that the deterrent effect of incarceration is small. ${ }^{14}$ Due to the lack of research on corporal punishment, comparisons are bound to be speculative, but a few things should be noted. ${ }^{15}$ First, we know from Daniel Kahneman's work on cognitive biases that people tend to judge the value of a future outcome based on prototypical instances of the outcome, while systematically failing to give sufficient weight to quantitative aspects, such as duration. ${ }^{16}$ Insofar as duration neglect applies to deterrence, we should expect to get a greater deterrence effect in return for each unit of harm that we inflict the greater the extent to which the harshness of the punishment is conveyed in the prototype. In that case, caning is likely to have a stronger deterrent effect than incarceration: while the prototype of incarceration (being in a prison cell) is itself not very upsetting, since the harshness is mainly produced by the duration, the prototype of caning (being caned) is much more likely to trigger strong aversive reactions.

Second, individuals that are prone to become criminals appear, on average, to have higher time-discounting rates (i.e., they give less priority to what is far into the future) than the population at large. ${ }^{17}$ Insofar as time-discounting rates are relevant to deterrence, we should expect to get more deterrence in return for each unit of harm that we inflict the closer in time the punishment follows from the crime. Although it is true that both incarceration and caning can start right after sentencing, the problem with incarceration is that the fourth year of a four-year prison sentence must, by necessity, lie at least three years into the future. By contrast, all twenty strokes with a cane can be delivered on the same day. Duration neglect and time discounting thus count in favor of caning. Although we should, of course, be careful not to infer causation from mere correlation, in discussing the deterrence potential of caning it should be pointed out that Singapore-where caning is a common method of punishment used for thirty-five different criminal offenses - is consistently ranked as having one of the lowest crime rates in the world. ${ }^{18}$

14 A central work on the limited deterrence effect of incarceration is Hirsch, Bottoms, Burney, and Wikström, Criminal Deterrence and Sentencing Severity. A large recent meta-analysis reached a similar conclusion, see Roodman, “The Impacts of Incarceration on Crime."

15 For a critical discussion of the findings of the Cadogan Committee of 1937, which evaluated the abolition of judicial corporal punishment in Britain, see Scarre, "Corporal Punishment," 300-302.

16 Kahneman, "Evaluation by Moments, Past and Future."

17 Åkerlund, Golsteyn, Grönqvist, and Lindahl, “Time Discounting and Criminal Behavior.”

18 For a comparison with the United States, see NationMaster, "Crime: Singapore and United States Compared." 
A final advantage is that corporal punishment is much cheaper than incarceration. Incarceration in the United States costs, on average, $\$ 30,000$ per inmate per year. ${ }^{19}$ This is only the direct cost paid by states; in addition, there is the cost incurred in cases where the convict would otherwise have been a productive member of the workforce. While the exact cost of caning has not been determined, it is much less time consuming and therefore also much less labor and capital intensive. Of course, cost is not all that matters in selecting a punishment method, but insofar as the resources that are currently spent on incarceration could have been spent on nobler goals (such as rehabilitation, compensation to victims, or improved conditions in prisons for convicts that must still be incarcerated), cost-effectiveness should be given some weight.

These six advantages of caning, taken together with the fact that caning cannot be rejected out of hand by the naive objections, constitute a pro tanto case for introducing caning into our penal repertoire. Let me now examine the objections.

\section{THE BETTER OBJECTIONS}

\subsection{Torture}

One important objection to corporal punishment, including caning, is that it is a form of torture, and that this makes it wrong. Is caning a form of torture? The answer depends on how we define torture. In the United Nations Convention against Torture, torture is defined as

any act by which severe pain or suffering, whether physical or mental, is intentionally inflicted on a person for such purposes [as] punishing him for an act he or a third person has committed or is suspected of having committed ... when such pain or suffering is inflicted by or at the instigation of or with the consent or acquiescence of a public official or other person acting in an official capacity. ${ }^{20}$

Since caning involves "severe pain or suffering," and is inflicted as a legal punishment, it very likely qualifies as torture according to the un definition. The challenge, however, is that according to this definition, many mainstream variants of incarceration also seem to qualify as torture.

In "What's Wrong with Torture?" David Sussman argues that it is central to

United States Bureau of Justice Statistics, "Direct Expenditures by Criminal Justice Function, 1982-2007." 
torture that "the victim takes her tormentor to be someone who can do anything he wants to her," that the victim is "exposed to a will that appears largely if not completely arbitrary," and that the tormentor is indifferent to the victim's rights. ${ }^{21}$ In the case of caning, however, the person who inflicts the punishment cannot do whatever they want and the convict knows it. The convict also knows that within a few minutes the caning will come to an end, and they know for certain that they will not be killed. Moreover, the convict's punishment is not arbitrary and their rights are clearly defined. Therefore, although caning has some central features in common with torture-most obviously the deliberate infliction of intense pain-it is also different in important respects. Caning might be categorized as torture, but it might also be a borderline case. ${ }^{22}$

I would like to suggest that not very much hinges on whether we categorize caning as torture. Although the way we categorize caning is relevant to the descriptive question of which laws would need rewriting for caning to be introduced into the penal code of a given country, it is not so relevant to the normative question of whether caning is a punishment that our laws ought to permit in the first place. In order to answer the normative question, we must confront what is arguably the more fundamental and substantive question at stake in assessing corporal punishments vis-à-vis incarceration, namely: Is it more justifiable to inflict mild- to medium-intensity psychological pain over long stretches of time (as in the case of incarceration) than to inflict very intense bodily pain over a very short stretch of time (as in the case of caning)?

\subsection{Degradation}

One substantive argument against the infliction of intense bodily pain is that it is degrading. Lenta argues that the reason it is degrading is that the "reactions on the part of the offender to the intense physical pain of judicial corporal punishment will more often than not be immediate and reflexive, not based on reasons so much as causes" and that "an offender who undergoes judicial corporal punishment may experience not only intense physical pain but also the emotional suffering resulting from his humiliating loss of self-control." ${ }^{23}$

It is true that an offender who is caned experiences emotional suffering resulting from a humiliating loss of self-control. In considering this objection, however, we must keep in mind that the same is very often true of offenders

21 Sussman, "What's Wrong with Torture?" 7-8.

22

Patrick Lenta argues that judicial corporal punishment is torture, but in his view, twisting someone's arm is also torture. Indeed, it is unclear if Lenta also categorizes standard forms of incarceration as torture. See Lenta, "Is Corporal Punishment Torturous?" 
that are incarcerated. Incarceration is not peaceful confinement to a prison cell; it includes frequent strip searches, intense surveillance, and detailed regulation of life, and for many inmates, it results in extreme desperation, isolation, lack of self-control, and destruction of character. ${ }^{24}$ Although it is undeniable that caning is much more degrading per time unit, caning lasts only for a few minutes whereas incarceration lasts for months or years. Given the psychological hardships associated with incarceration, it is therefore not clear that incarceration is in sum any more degrading than incarceration.

\subsection{Invasiveness}

A closely related argument, also proposed by Lenta, is that corporal punishment is more invasive than incarceration. ${ }^{25}$ Although an incarcerated man's body is forcibly locked in a prison cell, and although he might be forced to wear prison clothes and to comply with prison rules, the punishment does not invade his body the way caning does.

It is true that caning invades the body in a way that incarceration does not. We cannot take for granted, however, that bodily invasions are the only kinds of invasions that matter morally, or even that they are the invasions that matter the most. If we take a punishment to be invasive in case it strikes at and harms something intimate and personal, then incarceration will often be a very invasive punishment, the reason for which is that it strikes at a convict's relationships and emotions. Scarre, in criticizing incarceration, observes that "grief, disappointment, envy, frustration of projects, disillusion, boredom, lovelessness, lack of self-esteem or the esteem of others, insecurity, anger, etc. can be quite as severe spoilers of life as any physical sufferings." ${ }^{26}$ Moreover, since incarceration often takes away from convicts years that they could have spent with family or friends, and since they will never get that lost time back, incarceration frequently robs convicts of some of the most valuable and meaningful things in life. The result is that while we might perhaps be able to pay proper damages to someone who has been wrongfully caned, it is much harder to see how we could properly compensate anyone for having missed several years of their children's lives.

\subsection{Teaches the Wrong Lesson}

It can also be argued that caning teaches the wrong lesson: the lesson that violence is an acceptable method of conflict resolution. "Corporal punishment," Lenta writes, is "a type of punishment that humiliates and shames offenders"

24 Jacobs, "From Bad to Worse."

25 Lenta, Corporal Punishment, 208-9.

26 Scarre, "Corporal Punishment," 306. 
and that is therefore "less likely to be successful in driving home the message that their degradation of their victims is morally unacceptable." ${ }^{27}$ I concede that in some cases, caning might seem paradoxical. If we cane a convict for violent assault, we can find ourselves in a situation where we are hitting someone in order to teach them that hitting is wrong. Paradoxical as this might seem, I do not think this is a weighty objection to caning, since it is uncontroversial that punishments may resemble crimes. A person can be fined for stealing money or incarcerated for kidnapping. In these cases we do not think that the reaction is paradoxical, the reason for which is presumably that we see that there is an important moral difference between, on the one hand, committing crimes, and on the other hand, inflicting a cost on those who commit crimes, irrespective of the surface resemblance of the two actions. It is unclear why this is a greater problem in the case of caning than in the case of fining or incarceration. ${ }^{28}$

\subsection{Violence}

An alternative objection is that the problem with corporal punishment does not lie specifically in the apparent similarity between crime and punishment, but in the very violent nature of corporal punishment, which sanctions and normalizes violence. Judicial corporal punishment, Lenta argues, brutalizes us. ${ }^{29} \mathrm{He}$ argues that there is a danger that if we allow states to cane convicts, then even if this happens in prisons, out of public view, we undermine the taboo on violence in society.

This, I think, is Lenta's strongest objection. If states act violently, they communicate that violence is an acceptable way to resolve conflicts, and this, in turn, might undermine important social norms that curb the use of violence.

In assessing the weight of the objection, we must keep in mind that states, through the military and the police, already use violence, and that most of us accept that they are sometimes justified in doing so. States, by their nature, hold a monopoly on violence, and must sometimes act violently. Here it might be said, in response, that the example is disanalogous, since when the police or the military use violence justifiably, they do so because it is necessary, but if a convict is caned that is not really necessary. I would like to suggest, however, that there is no morally relevant difference here. Although it is true that the police might have to act urgently in deciding, for example, whether or not to shoot at someone who has taken a hostage, we must keep in mind that in practical affairs, the claim that " $x$ is necessary" presupposes some end that is conditional. In this example, shooting might be necessary in order to prevent the hostage taker from taking

27 Lenta, Corporal Punishment, 211.

28 David Benatar makes this argument. See Benatar, “Corporal Punishment.”

Lenta, Corporal Punishment, 197. 
more hostages. It is not necessary in the sense that nothing else could happen and thus we could, if we wanted, have made laws that prevented the police from ever shooting at hostage takers. We do not want such laws, however, because of the negative effects that they would have.

We face the same conditional necessity in the case of corporal punishment. Given the way society is - and given that we want to create a significant deterrent effect in a way that is financially affordable and that does not ruin the convict's ability to reintegrate into society-it might well be necessary (again, conditionally necessary) to inflict a corporal punishment, since all of the alternatives might be even worse. The real difference between shooting a hostage taker and caning a criminal lies not in the necessity, but in the urgency, of reacting in a violent manner. It is difficult to see, however, how urgency itself could be morally relevant, other than, perhaps, by allowing a larger margin of error. Nevertheless, we should concede that caning is a violent act, and to the extent that it is in sum more violent than incarceration (in spite of its much shorter duration), this counts against caning.

\subsection{Fairness}

A different type of objection is that, contrary to what I argued earlier, caning is in fact not fairer than incarceration: people have different pain thresholds, whether due to biological factors or practice with handling violence and pain, and therefore caning is much worse for some than for others. ${ }^{30}$

The weight of this objection depends on how we understand pain thresholds. On one interpretation, people with a high pain threshold are those that have fewer of the typical behavioral responses to pain. Some can clench their teeth and remain stoic even if the pain they experience is excruciating. To the extent that this is what we mean by a high pain threshold, differences in pain thresholds do not matter fairness-wise. Presumably, it is the felt pain that is the central bad-making property of caning, and the felt pain can be the same irrespective of the person's responses. In another interpretation, people with a high pain threshold are those that experience less pain from the same physical stimuli. Only to the extent that the latter is the right interpretation do differences in pain threshold matter justice-wise.

We should grant that some convicts are likely to feel less pain from a caning than others. We must keep in mind, however, that the same is true of the psychological pains of incarceration: While some inmates are thrown into depression for life after being incarcerated, others are much less affected. We should probably expect that, on average, social isolation harms extroverts more than 
it harms introverts, and while some inmates find comfort in having a family on the outside, for others being separated from their family is excruciating. Unless we have a reason to believe that the differences in felt pain are greater in the case of caning than in the case of incarceration, this objection fails. Moreover, since incarceration has the added unfairness of being much more dangerous for certain groups (inmates that are not physically intimidating, transgender inmates, inmates serving time for child sex offenses, etc.), fairness considerations seem, in sum, to count somewhat in favor of caning.

\subsection{Incapacitation and Rehabilitation}

Another type of objection is that we often need to do more than just punish: we might also need, for instance, to incapacitate, i.e., to keep criminals away from civil society in order to prevent them from causing further harm. Lenta argues that while incarceration achieves this goal, corporal punishment does not. ${ }^{31}$ If, moreover, we reserve corporal punishment for relatively serious offenses, these will typically be just those offenses that require some form of incapacitation anyway, and since we must incapacitate these offenders by incarceration, inflicting corporal punishment will be redundant.

I concede that incarceration is sometimes a useful way to jointly achieve punishment and incapacitation. While incapacitation is needed in some cases, however, there are other cases - such as fraud, corruption, vandalism, theft, and burglary—that seldom require incapacitation. In these cases, caning might be a viable option.

Even in cases where we need to incapacitate, however, we cannot take for granted that incarceration is always the most effective means to achieve that goal. In some (but admittedly not all) cases, GPS-monitored house arrest, which is much cheaper than incarceration, can be sufficiently incapacitating. Today, this option must sometimes be rejected, not because house arrest fails to be sufficiently incapacitating, but because it fails to be sufficiently punishing. If we disentangle incapacitation and punishment, we can, when needed, sentence a convict to caning followed by house arrest.

In cases where we seek not just to incapacitate, but also to rehabilitate, we might have an additional reason to keep the responses separate, namely that punishment and rehabilitation have very different aims. While the aim of punishment is to make convicts worse off, at least temporarily, the aim of rehabilitation is to help them become better-functioning members of society. When rehabilitation and punishment are pursued jointly, the institution that helps convicts improve must also impose deliberate burdens. To the extent that this hinders

31 Lenta, Corporal Punishment, 198. 
rehabilitation, we might have a reason first to inflict a corporal punishment and then to send a convict to a forced, yet not intentionally unpleasant, rehabilitation program. (To the extent that the rehabilitation is itself burdensome, the punishment would need to be made less severe or eliminated so that the convict is not burdened twice for the same crime.)

Here it might be said, in response, that rehabilitation encompasses much more than what goes on in formal rehabilitation programs. Reflection on past choices and feelings of regret are also important forms of rehabilitation. Lenta suggests that incarceration can "provide [offenders] with an opportunity for self-reform where conditions are such that inmates are not unacceptably degraded and constantly terrorized." ${ }^{32}$ It is true that while incarceration gives room for thought, caning does not: it is over too quickly, and while it lasts, it produces only agony. Nevertheless, just as we cannot assume that locking people in a prison cell for a long time is the most effective form of punishment, we cannot assume that it is the most effective way to elicit reflection and regret. Reflection and regret can be pursued through many different means, including short-term incarceration, psychotherapy, empathy training, meeting with victims, and possibly even through psychopharmacology. ${ }^{33}$

Incarceration is a package deal that combines punishment, incapacitation, and (sometimes) rehabilitation. Although this package is a useful response in the case of some crimes, in other cases it is too blunt a tool. Sometimes we can accomplish more of our goals, and do so at a lower cost and with less long-term damage, if we seek to pursue the goals of punishment, incapacitation, and rehabilitation separately. If we add caning to our penal repertoire, we get a means to do that.

\subsection{Scars and Lasting Psychological Damage}

Yet another objection is that caning can create physical scars. This a genuine downside to its most severe forms. In evaluating the weight of the objection, however, a few things must be kept in mind. On the one hand, many scars from caning are only temporary, and even permanent scars remain relatively private because they are confined to the buttocks. On the other hand, if we are concerned with scarring, then the caning method might be modified. In Singapore, military canings are carried out with a thinner cane and with a thin layer of protective clothing, which drastically reduces the likelihood of scars. ${ }^{34}$ Although scarring is an important consideration, this problem can be minimized, and in-

32 Lenta, Corporal Punishment, 211.

33 For the last point, see Pugh and Maslen, “'Drugs That Make You Feel Bad?”

34 World Corporal Punishment Research, "Singapore: Caning in Military Forces." 
sofar as prison environments are likely to be violent, incarceration can also leave permanent scars.

It might further be argued that caning causes lasting psychological damage, such as severe anxiety and PTSD. These are all well-known effects of torture. ${ }^{35}$ Are these also effects of caning? Since there is little research on caning, we do not know, but this is certainly a danger. We must keep in mind, however, that the differences between caning and torture that we discussed above-such as the victim's having clear rights and knowing that her punishment will soon be over and will not kill her-give us some reason to believe that it is psychologically less harmful than torture. In caning, the harm lies just in the pain. We must also keep in mind that incarceration, which is our contrasting method in this paper, often causes lasting psychological problems, including hypervigilance, interpersonal distrust, social withdrawal, and PTSD. ${ }^{36}$

Irrespective of which method of punishment we use, it is very difficult to punish in ways that do not cause lasting damage, especially if we wish to punish rather severely. The question is how we can minimize lasting damage. Given the available evidence, it is not at all clear that incarceration is better than caning in this respect.

A different appeal to psychological damage focuses on the damage done to the caner. This objection to judicial corporal punishment was considered by Jeremy Bentham, who suggested, idiosyncratically, that we might solve it by building a whipping machine that can carry out corporal punishments for us. He even made blueprints for such a machine. ${ }^{37}$ Although whipping machines cannot be rejected out of hand, they are probably not necessary. Police officers and soldiers already carry out very harmful actions, even killings, and many of these actions seem worse than caning. I, at least, would much rather be caned than killed, and I would also much rather cane someone than kill them.

We must be careful, in assessing how bad it would be to carry out a caning, that we do not presuppose that caning is never justified. If caning is never justified, it would indeed be very bad to carry it out, but that takes for granted what is sought by the objection. If caning is otherwise justified, it might be a lesser evil to be opted for in situations that are inescapably very bad, and in that case, it becomes more difficult to explain why caning convicts is morally different from other forms of violent police and military operations. We must also keep in mind that while a country needs thousands of prison guards, it needs only a few 
caners. The total damage to those who inflict punishments, therefore, might still be lower if we introduce caning.

It might be objected that jobs that involve caning would attract sadists. As long as the procedure is closely monitored and regulated, however, it is hard to see why this would be a significant problem. It is much more worrisome that people with sadistic inclinations end up in law-enforcement positions that are less ordered and less transparent, such as the position of being a prison guard.

\subsection{Slippery Slope}

It can be argued that if we accept judicial caning, we move onto a slippery slope where we will gradually accept even harsher punishments. As with all slippery-slope arguments, this argument can be interpreted either as a logical or as a causal argument. Interpreted as a logical slippery-slope argument, the argument states that if we accept caning, then we are also committed to accepting even harsher forms of punishment, which we ought not to accept. Thus construed, slippery-slope arguments are modus tollens arguments (if $P$, then $Q$; not $Q$; therefore, not $P$ ). Although it is true that caning would open up a new category of punishments in countries in which corporal punishment is currently banned, it is unclear why that would commit us, on pain of contradiction, to accept even harsher punishments. It is clearly consistent to claim that, granted the cost, the harm to the convict, and the deterrence, caning on the Singaporean model is exactly what we are justified in inflicting.

Interpreted causally, the slippery-slope argument states that if we accept caning, then it is a social and psychological fact that we will very likely come to accept even harsher punishments. This is an argument not about what is logically entailed, but about what is likely to result, causally, if we start caning convicts. This argument is better, but it is empirically vulnerable. There appears not to be any escalation in the severity of caning in countries that permit it. This, arguably, places the burden of proof on those who believe that caning would lead to escalation. Notice also that evidence of escalation alone would not be sufficient for the argument to be successful, for we would need to see not just any escalation, but an escalation beyond what is justifiable (an escalation within the range of the justifiable is presumably not morally problematic), and for the objection to be weighty in the context of our discussion, it would also have to be unlikely that we would be able to take deliberate legal measures to avoid such an escalation if we introduce caning.

Another variant of the causal slippery-slope argument appeals not to a legal expansion or intensification of corporal punishment, but to an increased acceptance of the corporal punishment of children. Although it is possible that insti- 
tutionalizing judicial corporal punishments would have this effect, and though there is almost certainly a positive correlation between countries that accept judicial corporal punishment and countries that accept the corporal punishment of children, it does not follow that if a country starts accepting judicial corporal punishment, then it is thereby more likely to become more accepting of the corporal punishment of children. After all, it is not common to conclude that the things that the state may do to adult criminals are also things that parents or teachers may do to children. My own view is that children should not be subject to corporal punishment, one reason for which is that children are both more vulnerable and less responsible for their actions than adults. Moreover, while corporal punishment in the judicial system can be tightly regulated to prevent abuse, the corporal punishment of children will often take place in less regulated environments, which is riskier. Finally, one of the central advantages of judicial corporal punishment-namely that, unlike incarceration, it does not harm dependents and does not ruin the convict's social and professional life in the future-does not apply in the case of children. For these reasons, I think it is puzzling that in the US and the UK, and in many other countries, the corporal punishment of children is permitted but the corporal punishment of adult criminals is condemned. It would have made more sense if it were the other way around.

\subsection{Barbarism}

The last argument that I shall consider is that corporal punishment is barbaric, and that this gives us reason to reject it. In order to assess this objection, we need some understanding of what we mean when we say that something is "barbaric." On the one hand, it might mean that this is a punishment method used by "barbaric" regimes. Thus stated, the appeal to barbarism would be a guilt-by-association fallacy, since presumably no punishment method is made wrong in virtue of being used by barbaric regimes. The punishment method would have to be wrong in virtue of some other feature, which in turn could help explain why the regime, in employing the punishment, is barbaric. It is not clear that barbaric regimes would be any less barbaric if they replaced their corporal punishments with equally harsh forms of incarceration.

It could be suggested, alternatively, that corporal punishments provide barbaric regimes with a way to deter opposition. This is unconvincing. Long-term incarceration also deters opposition, and while long-term incarceration keeps political opponents locked away so they cannot participate in public debate, caning does not have this effect.

Another variant of the barbarism objection might be that in a country like the United States, which has a legacy of slavery and of whipping slaves, caning 
mirrors a grave historical injustice. This could be a particularly pressing issue if, in practice, black Americans were caned disproportionately, which is not an unlikely outcome, given that black Americans already constitute a disproportionately large percentage of prison inmates. ${ }^{38}$ Although this is a reasonable objection, it is a local one, and even in the American context we must ask why caning black Americans mirrors slavery to a larger degree than incarcerating black Americans, given that incarceration takes away black inmates' freedom and forces them to obey orders given by predominantly white prison guards. ${ }^{39}$ If caning mirrors slavery, so, arguably, does incarceration. Given the additional hardships that incarceration imposes on black families in the United States, this is not a weighty objection. ${ }^{40}$

The most straightforward variant of the barbarism objection is that caning is barbaric simply in virtue of being viscerally extremely upsetting. In this respect I think we must concede that caning is barbaric. I would like to suggest, however, that rather than being a reason to reject caning, this is in fact one of its virtues. There are two reasons for this. One reason is that the more viscerally upsetting a method of punishment is, the more deterrence we are likely to get per unit of harm that we inflict. To the extent that we want the most deterrence and the least overall harm, this is good, and from that perspective, the worst strategy that a society could choose would be to inflict punishments that are very harsh on convicts, yet whose harshness is hidden such that we get very little deterrence in return. This, sadly, might be a feature of incarceration.

The other reason why a judicial punishment ought to be viscerally upsetting is that when the government acts brutally and inflicts harm, it is better that it does so explicitly and honestly, and in a way that makes its brutality intelligible to its citizens. If we send someone to prison for a year, this might not strike us as a very drastic measure, even though it could ruin that person's life. If, on the other hand, we sentence them to ten strokes with a cane, it is much more difficult for us to punish under the guise of mere incapacitation and rehabilitation. Punishments hurt, and caning makes this painfully explicit to all parties.

\section{CONCLUSION}

Judicial corporal punishment might lead to increased acceptance of violence, and it might also give convicts lasting physical scars and mental health problems.

Black Americans constitute thirteen percent of the population at large and forty percent of the prison population. Sakala, "Breaking Down Mass Incarceration in the 2010 Census."

Gandy, "In Prisons, Blacks and Latinos Do the Time While Whites Get the Jobs."

Western and Wildeman, "The Black Family and Mass Incarceration." 
While these downsides are real and should be taken very seriously, I have argued that they are insufficient to reject this method of punishment. Incarceration, which is today's norm, also involves violence (albeit less visibly), and we know for certain that it has lasting negative effects on the mental health of convicts. On the other hand, caning has several beneficial features: it costs less; it punishes only the convicts; it does not destroy the social and economic networks that many convicts depend upon to reintegrate into society after release; it does not cause convicts to socialize with other convicts over long stretches of time; it makes it harder for us to evade what we are doing when we punish; and it arguably gives us a greater deterrent effect in return for each unit of harm that we inflict.

For all I have argued here, it might be that we should not punish at all. It is possible that we should only incapacitate and rehabilitate. To the extent that we should continue to punish, however, corporal punishment in the form of caning is a method worth considering. ${ }^{41}$

\author{
University of Oslo \\ olemartinmoen@gmail.com
}

\title{
REFERENCES
}

Åkerlund, David, Bart H.H. Golsteyn, Hans Grönqvist, and Lena Lindahl. "Time Discounting and Criminal Behavior." Proceedings of the National Academy of Sciences 113, no. 22 (May 31, 2016): 6160-65.

Benatar, David. "Corporal Punishment." Social Theory and Practice 24, no. 2 (Summer 1998): 237-60.

Bentham, Jeremy. The Rationale for Punishment. London: Robert Heward, 1830. Boonin, David. The Problem of Punishment. Cambridge: Cambridge University Press, 2008.

Duff, Antony. Punishment, Communication, and Community. Oxford: Oxford University Press, 2003.

Edney, Richard. "To Keep Me Safe from Harm? Transgender Prisoners and the Experience of Imprisonment." Deakin Law Review 9, no. 2 (2004): 327-38.

Gandy, Rachel. "In Prisons, Blacks and Latinos Do the Time While Whites Get

41 I would like to thank Brian Earp and Aksel Braanen Sterri, two anonymous referees, and workshop participants at University of Oslo and Roskilde University for their thoughtful comments and helpful suggestions. Work on this paper was funded by the Research Council of Norway, project 259521. 
the Jobs." Prison Policy Initiative, July 10, 2015. https://www.prisonpolicy. org/blog/2015/o7/10/staff_disparities.

Haney, Craig. "The Psychological Impact of Incarceration: Implications for Post-Prison Adjustment." us Department of Health and Human Services, December 2001. http://aspe.hhs.gov/basic-report/psychological-impact -incarceration.

Hirsch, Andreas von, Anthony E. Bottoms, Elizabeth Burney, and P. O. Wikström. Criminal Deterrence and Sentencing Severity. Portland, oR: Hart Publishing, 1999.

Jacobs, Jonathan. "From Bad to Worse: Crime, Incarceration, and the Self-Wounding Society." In Justice and Penal Reform: Re-Shaping the Penal Landscape, edited by Stephen Farrall, Barry Goldson, Ian Loader, and Anita Dockley, 8-26. New York: Routledge, 2016.

Kahneman, Daniel. "Evaluation by Moments, Past and Future." In Choices, Values and Frame, edited by Daniel Kahneman and Amos Tversky, 693-708. Cambridge: Cambridge University Press, 2000.

Kinzie, David J. "Guidelines for Psychiatric Care of Torture Survivors." Torture 21, no. 1 (November 1, 2011): 18-26.

Lenta, Patrick. Corporal Punishment: A Philosophical Assessment. London: Routledge, 2018.

—. "Is Corporal Punishment Torturous?" Journal of Applied Philosophy 34, no. 1 (February 2017): 74-88.

Mariner, Joanne. No Escape: Male Rape in us Prisons. Human Rights Watch Report, 2001. https://www.hrw.org/reports/2001/prison/report.html.

Moskos, Peter. In Defense of Flogging. New York: Basic Books, 2011.

NationMaster. "Crime: Singapore and United States Compared." http:// www.nationmaster.com/country-info/compare/Singapore/United-States/ Crime.

Newman, Graeme. Just and Painful: A Case for the Corporal Punishment of Criminals. 2nd ed. New York: Harrow and Heston, 1995.

Parke, Ross D., and K. Alison Clarke-Stewart. "From Prison to Home: The Effects of Incarceration and Reentry on Children, Families, and Communities." us Department of Health and Human Services, December 1, 2001. https:// aspe.hhs.gov/basic-report/effects-parental-incarceration-young-children.

Pugh, Jonathan, and Hannah Maslen. "'Drugs That Make You Feel Bad'? Remorse-Based Mitigation and Neurointerventions." Criminal Law and Philosophy 11, no. 3 (September 2017): 499-522.

Roodman, David. "The Impacts of Incarceration on Crime." Open Philanthropy Project, September 2017. http://files.openphilanthropy.org/files/Focus_ 
Areas/Criminal_Justice_Reform/The_impacts_of_incarceration_on_ crime_10.pdf.

Sakala, Leah. "Breaking Down Mass Incarceration in the 2010 Census: State-byState Incarceration Rates by Race/Ethnicity." Prison Policy Initiative, May 28, 2014. https://www.prisonpolicy.org/reports/rates.html.

Scarre, Geoffrey. "Corporal Punishment." Ethical Theory and Moral Practice 6, no. 3 (September 2003): 295-316.

Sussman, David. "What's Wrong with Torture?" Philosophy and Public Affairs 33, no. 1 (January 2015): 1-33.

Trammell, Rebecca, and Scott Chenault. "'We Have to Take These Guys Out': Motivations for Assaulting Incarcerated Child Molesters." Symbolic Interaction 32, no. 4 (Fall 2009): 334-50.

United Nations General Assembly, Resolution 39/46, Convention against Torture and Other Cruel, Inhuman or Degrading Treatment or Punishment (December 10, 1984). https://undocs.org/en/A/RES/39/46.

United States Bureau of Justice Statistics. "Direct Expenditures by Criminal Justice Function, 1982-2007," December 2011. http://www.bjs.gov/content/ $\mathrm{pub} / \mathrm{pdf} /$ jee8207st.pdf.

Western, Bruce, and Christopher Wildeman. "The Black Family and Mass Incarceration." Annals of the American Academy 621, no. 1 (2009): 221-42.

World Corporal Punishment Research. "Judicial Caning in Singapore, Malaysia and Brunei." 2019 ed. http://www.corpun.com/singfeat.htm. . "Singapore: Caning in Military Forces." http://www.corpun.com/ counsga.htm. 